РОЗДІЛ ІІІ. ПРОБЛЕМИ ЗАГАЛЬНОї ПЕДАГОГІКИ

удк 378.091.3

Світлана Атаманюк
Національний університет «Запорізька політехніка»
orcid.org/0000-0002-4800-5965
DOI 10.24139/2312-5993/2020.10/315-324

\title{
ВИКОРИСТАННЯ ІННОВАЦІЙНИХ ВИДІВ РУХОВОЇ АКТИВНОСТІ У ПРОФЕСІЙНІЙ ДІЯЛЬНОСТІ ФАХІВЦІВ ФІЗИЧНОЇ КУЛЬТУРИ І СПОРТУ
}

Інновачійні програми фрізичної культури і спорту призначені для того, щоб бути більш всеосяжними, динамічними, рухливими, відкритими, ніж традиційні заняття фізичною культурою та спортом. Це допомагає виконувати фізичні навантаження й виробляти прихильність здоровому способу життя, здійснювати заняття фізичною культурою і спортом самостійно, навчити різні верстви населення руховій діяльності, підкреслюючи психологічний вплив фізичних вправ на стан здоров'я. Інноваційні види рухової активності, втілені в нових програмах, дозволяють фахівцям фрізичної культури і спорту розвивати в підопічних різні рухові навички та здатності працювати в команді, при цьому вихованці відчувають себе більш комфортно в руховому середовищі.

Ключові слова: фахівці фрізичної культури і спорту, інноваційні спортивні технології, рухова активність, технології здоров'я та фрітнесу, цифрові технології спорту та здоров'я.

Постановка проблеми. Інноваційна освіта - це розвиток і розширення якісної освіти, життєво важливий спосіб розвивати творчість, здібності й таланти вихованців із високою якістю. У сучасну епоху з розвитком інформаційних і комунікаційних технологій удосконалюються різні спортивні й фізкультурні програми. Інноваційні програми фізичної культури і спорту (ФКіС) призначені для того, щоб бути більш всеосяжними, динамічними, рухливими, відкритими, ніж традиційні заняття фізичною культурою та спортом. Це допомагає виконувати фізичні навантаження й виробляти прихильність здоровому способу життя, здійснювати заняття фізичною культурою та спортом самостійно, навчити різні верстви населення руховій діяльності, підкреслюючи психологічний вплив фізичних вправ на стан здоров'я. Інноваційні види рухової активності, втілені в нових програмах, дозволяють фахівцям фізичної культури і спорту розвивати в підопічних різні рухові навички та здатності працювати в команді, при цьому вихованці відчувають себе більш комфортно в руховому середовищі.

у цьому контексті впровадження інноваційних видів рухової активності у професійній діяльності фахівців фізичної культури і спорту викликає інтерес як нова парадигма для організації занять (Chesbrough, 2003), а також фахівцям ФКіС було б корисно «систематично заохочувати й 
вивчати широкий спектр внутрішніх і зовнішніх джерел інновацій та нових можливостей, свідомо інтегруючи ці дослідження зі стійкими можливостями й ресурсами та широко використовуючи ці можливості в різних напрямах» (West and Gallagher, 2006). Таким чином, актуальною $€$ проблема вивчення інноваційності в спортивних і фізичних програмах.

Аналіз актуальних досліджень. Розвиток галузі фізичної культури і спорту ґрунтуються на Постанові Верховної Ради України «Про забезпечення сталого розвитку сфери фізичної культури і спорту в Україні в умовах децентралізації влади» (2016), Цільовій соціальній комплексній програмі розвитку фізичної культури і здоров'я (2016) та ін.

Концептуальні, теоретичні й методичні засади діяльності фахівців у галузі ФКіС розкрито в роботах О. Ажиппо, О. Томенко, Ю.Лянного, О. Міхеєнка, П. Рибалка, Д. Бермудес, Н. Бєлікової, Б. Долинського, М. Носко та ін. Значний науковий внесок у розвиток теорії фізичного виховання і спорту зробили вітчизняні вчені С. Бубка, М. Дутчак, І. Максименко, В. Платонов, Ю. Бріскін, В. Костюкевич, А. Магльований та ін. Дослідники розкрили у своїх працях провідні напрями оптимізації підготовки спортсменів.

Фізична культура і спорт є важливою частиною нашого життя, що стає все більш популярною. Тренувальні заняття зберігають здоров'я, надають розслабленість, а також підтримують фігуру та зміцнюють соціальне, психологічне та духовне здоров'я через виховання терпіння й витривалості. Також фізичне виховання і спорт $€$ процесом, де відбувається одна із соціальних активностей людей, яка визнається в суспільстві по всьому світу, а тому є засобом зближення людей (Eitzen and Sage, 2003). Участь у спортивних заходах і тренуваннях дозволяє відчувати себе частиною надійної групи та засвоїти відчуття приналежності (Allen et al. 2008). Також дослідники вважають, що фізичне виховання і спорт приносить користь або задоволення для здоров'я, коли люди збираються разом, але для багатьох учасників це $\epsilon$ досвід, який нерозривно пов'язаний із їх індивідуальністю та самооцінкою (Weiss et al., 2001). Іншими словами, фізичне виховання і спорт може використовуватися як спосіб збереження своєї культурної самобутності (Stodolska and Alexandris, 2004). Тому люди, які не займаються спортом, можуть втратити цінні можливості для соціалізації, освіти й навіть професійного розвитку (Majumdar et al., 2012). Пропаганда фізичної культури і спорту - це позитивний вплив на добробут, здоров'я і, отже, зменшення на витрати, які супроводжують медичне обслуговування (Pawlowski et al., 2014). у цьому контексті необхідно просувати участь різних верств населення в заняттях спортом, надаючи адекватну спортивну інфраструктуру (Wicker et al., 
2013). Це розвиває навички, знання, цінності й установки, необхідні для формування й ведення активного та здорового способу життя, а також формування впевненості й компетентності у вирішенні задач за допомогою широкого спектру заходів. Це також підхід до підвищення фізичної активності молоді та зниження хронічних захворювань (Hilland et al., 2016). Фізичне виховання і спорт створює раціональну основу для залучення молоді в регулярну структуровану фізичну активність, а також допомагає накопичити знання, навички й підходи, що дозволяють брати участь у інноваційній фізичній активності протягом життя (Heath et al., 2012). Іншими словами, фізична активність може розглядатися як важливий аспект якості життя та $є$ свідченням організованої фізичної активності (Kilborn et al., 2016). Фізичне виховання підтримує особисте й суспільне благополуччя, допомагає досягти високого рівня фізичної активності та фізичної підготовки для всіх; заохочувати надбання рухових навичок; розвивати нові підходи й розробляти конкретні технології, призначені для задоволення потреб усіх у фізичному зростанні й розвитку.

Водночас проведений аналіз наукових робіт показує недостатність систематичних теоретичних і практичних досліджень використання інноваційних технологій у професійній діяльності фахівців ФКіС. Ця проблема потребує додаткового осмислення й дослідження.

Мета статті. Розглянути основи використання інноваційних видів рухової активності у професійній діяльності фахівців фізичної культури і спорту.

Методи дослідження. Теоретичні методи: системний аналіз наукової, психолого-педагогічної, методичної літератури; узагальнення й систематизація теоретичних відомостей щодо професійної діяльності фахівців фізичної культури та спорту. Емпіричні методи: анкетування для вивчення реального стану професійної діяльності фахівців фізичної культури та спорту.

Виклад основного матеріалу. Інновація - це процес, за допомогою якого створюються нові активи або розвивається новий потенціал для дій. Інновації - це ключ до конкурентної переваги в складних мінливих умовах. Це важливе джерело зростання ринку й економіки, а значить і всіх інших галузей суспільного життя. У складному й мінливому середовищі інновації створюють цінність і стійку перевагу, а також допомагають працювати краще та створювати нові продукти й послуги (Hana, 2013). Іншими словами, інновація може розглядатися як прийняття нової ідеї, продукту, методу або послуги. Крім того, інновації як упровадження винаходів і модифікованих продуктів і послуг мають комерційну цінність та розглядаються як процес або послідовність подій, у яких люди взаємодіють один з одним, щоб привнести 
нові ідеї в організацію. Інноваційний потенціал відображає тенденцію до новизни, експериментів і творчого процесу, які допомагають у зростанні та диверсифікації. 3 іншого боку, це вважається успішною експлуатацією нових ідей. Іншими словами, це процес створення нових речей і явищ за допомогою необхідних технологічних каналів і творчого мислення (Comlek et al., 2012). Для того, щоб успішно рухатися вперед, необхідно приділяти підвищену увагу інноваційним проєктам. Це повинно стати ключовим моментом в організації практичної роботи з фізичного виховання та спорту. Упровадження інноваційних технологій дозволяє на якісно новому рівні вести тренувальний процес і розвивати спорт для всіх.

Сьогодні інноваційні технології здоров'я та фітнесу не $є$ надбанням особистого досвіду окремих фахівців, але вони розвиваються відповідно до досягнень медичної науки. Будь-яка технологія фізичної культури й оздоровлення включає в себе постановку мети й завдань реабілітації та фактичну реалізацію занять фізичною культурою та фітнесом у тій чи іншій формі.

Серед інноваційних технологій для здоров'я та фітнесу нині актуальними є: розтяжка, розтяжка іграшок (для дітей дошкільного віку), техніка прес-танцю (вправи на степ-платформі, степ-аеробіка, Zumba, степ, степбазік +ядро, StepmiSculpt, doublestep), dancemix, hotiron (Тренування з міні-баром), Crossfit (кругове тренування без відпочинку), фітбол (вправи з великим пружним м'ячем), ABL (дослідження ніг, комплекс вправ пілатес, йога і стретчінг), бодіскульт (силові тренування, проводяться в аеробіці), слайд, тренінг «Bosu» Platform.

Наприклад, стретчинг - це комплекс вправ, призначений для того, щоб м'язи були еластичними, а суглоби гнучкими й рухливими. Фахівці вважають, що у стретчинга є багато плюсів:

а) завдяки розтягуванню м'язів до них надходить більше крові, вони розслабляються та стають більш еластичними;

б) суглоби набувають більшої рухливості, в результаті чого збільшується гнучкість;

в) краща профілактика проти відкладення солей;

г) зосереджене, глибоке дихання благотворно впливає на головний мозок, особливо після трудового дня;

д) можливість займатися вдома самостійно, в зручний час.

Нові потреби, вимоги й інтереси в галузі ФКіС диктують необхідність в отриманні нових знань, за допомогою яких фахівець зможе самостійно розробляти нові фізкультурно-оздоровчі та спортивні програми й методики. 
Нами було здійснено анкетування тренерського складу відомих мережевих спортивних залів і спортивних клубів України (126 респондентів, проводилося за допомогою Google платформи). За його результатами відзначимо, що спортивні зали та клуби сьогодні представляють нові оздоровчі технології за таким принципом - синтез технологій: Zumba-step (вправи Zumba + steppl form), ABL (черевна порожнина + сідниці + ступні в програмі), Dancemix (суміш елементів різних танцювальних стилів минулого й сьогодення), Wellnessmix (Pilates + програма індивідуальних тренувань) та ін.

Виявлення провідних елементів рухів, що забезпечують основний ефект рухової дії під час навчання й удосконалення техніки у спортивних тренуваннях, гімнастичних вправах і єдиноборствах, має велике значення, оскільки, з одного боку, оцінка ролі елементів рухів дозволяє більш цілеспрямовано будувати навчально-тренувальний процес, а 3 іншого особливості виконання геотехнічних дій дозволяють порівняно простими прийомами виявляти провідні елементи рухів, використовуючи моделі $з$ малою кількістю ланок тіла. У простих вправах іноді можна якісно оцінити роль елементів рухів. У складних вправах, коли роль елементів руху залежить від сукупності рухових дій багатьох ланок тіла, часто буває важко взагалі виявити провідний елемент руху, навіть не зачіпаючи питання про кількісну оцінку його ролі. у більшості випадків результативність рухової діяльності можна виразити будь-якою однією, основною, провідною біомеханічною характеристикою (або сукупністю таких характеристик).

Так, під час піднімання ваги, вставання з присіду й у низці інших подібних випадків провідною біомеханічною характеристикою $\epsilon$ зміна ординати загального центру ваги системи «людина - вага» або, відповідно ординати центра ваги тіла людини (ОЦТ). У стрибках вгору з місця основним біомеханічних параметром опорного періоду $\epsilon$ швидкість ОЦт тіла в момент припинення зв'язку з опорою, яка характеризує висоту його польотної фази. За умови зміни статичної сили основним біомеханічним параметром $\epsilon$ амплітуда зусиль взаємодії з опорою. У зіскоках сальто назад із поперечини провідними параметрами опорного періоду є: вектор швидкості ОЦТ тіла й обертальний імпульс у момент припинення зв'язку 3 опорою, що характеризують поступальний і обертальний рух у безопорній фазі зіскоку.

Аналогічно для кожного руху людини, для будь-якої спортивної вправи можна з огляду на призначення, цільову спрямованість і очікуваний результат рухової дії знайти одну (або декілька) провідних, основних біомеханічних характеристик. Очевидно, що роль провідних елементів 
рухів повинна оцінюватися за їх впливом на провідну, основну біомеханічну характеристику руху.

Для того, щоб успішно орієнтуватися в різних напрямах використання сучасних біомеханічних ергогенних засобів у спорті, необхідно знання закономірності просторового орієнтування тіла спортсмена щодо різних систем координат, а також основних причин, що викликають ті чи інші рухи тіла людини. Виявлення ролі провідних елементів рухів дозволяє тренерам і їх підопічним акцентувати увагу на вирішальних ланках руху і на цій основі домагатися підвищення результативності спортивних вправ. Саме на цій основі створюються новітні інноваційні види рухової активності.

Анкетування тренерського складу відомих мережевих спортивних залів і спортивних клубів України дозволило виявити, що сьогодні у процес фізичних тренувань, нарощення сили, мускулатури, швидкості, витривалості активно упроваджуються новітні цифрові технології, тим самим забезпечуючи інноваційність процесу рухової активності за самою сутністю цього поняття.

Наприклад, досить корисну технічну новинку розробила фінська компанія Fam Sports. Пристрій для заняття спортом розрахований на струми невеликої напруги та служить для стимуляції нервово-м'язових реакцій мозку. Прилад усього за 15 секунд дає повну оцінку стану організму. Назва даного приладу Check (рис. 1).

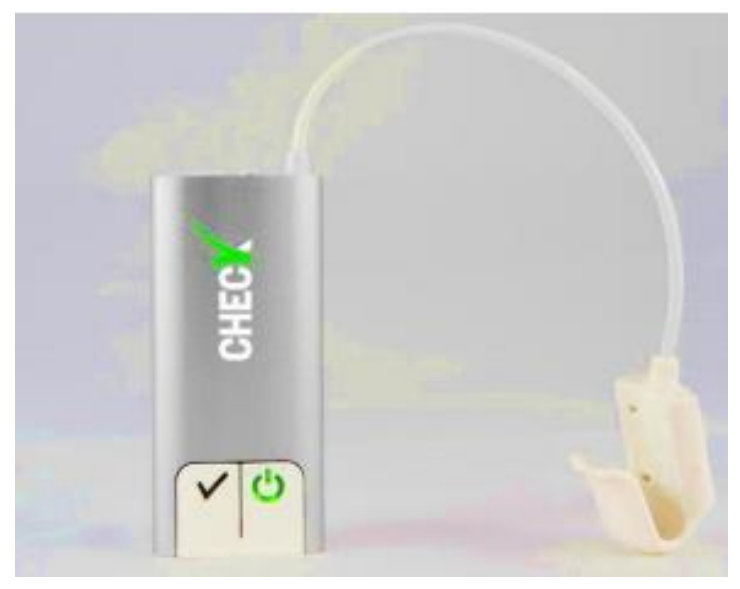

Рис. 1. Прилад Check для стимуляції нервово-м'язової реакції мозку

Він також дає сигнал у момент, коли тренування може нашкодити або призвести до травми. Принцип дії приладу дуже простий. Електроди кріпляться на кисть руки, далі прилад шляхом передачі малих електричних імпульсів на організм спортсмена передає електричний струм через тіло в мозок. Реакція організму на таку дію фіксується в додатку на смартфоні, а далі видається вся необхідна інформація для подальших дій. Розробники стверджують, що прилад буде корисний тим, хто займається вправами, які вимагають силу, координацію, а також швидкість. У наші дні все більшу 
популярність набирають фітнес-трекери або фітнес-браслети. Виглядають вони як звичайний електронний годинник, однак виконують колосальну роботу. Виміри серцебиття, кількість витрачених калорій, дистанція ходьби й бігу, рівень споживання рідини та багато іншого входять у стандартний набір обчислень даних браслетів. Найпопулярнішими фітнес-трекерами на сьогодні є: Xiaomi M iBand 3 i Samsung GearFit 2 (Kokoulina, Simina \& Tatarova, 2019).

у 2000 році австрійський лікар спортивної медицини, фізіолог Норберт Еггер запропонував унікальний тренажер, що дозволяє виконувати фізичне навантаження в умовах зниженого й підвищеного атмосферного тиску для окремих сегментів тіла. Це призводило до значного збільшення інтенсивності кровообігу в області живота й нижніх кінцівок і забезпечувало активне надходження кисню до жирової тканини. У підсумку виконання помірного навантаження призводило до зменшення жирової клітковини в місцях, де звичайними тренуваннями та дієтою позбутися жиру було надзвичайно важко. Тренажери НYPOXI представлені у вигляді капсул із велотренажером усередині, в яких моделюється режим зміни тиску й навантаження, що дозволяє активно вирішувати проблему жировідкладення на стегнах і в нижній частині живота. Ці тренажери особливо ефективні для жінок із грушоподібною статурою, які мають проблеми з жировим відкладенням у зоні стегон. Також дана методика застосовується для профілактики захворювань вен і венозного застою, шляхом використання в ній компресійної методики, стимулюючої судини, яка прискорює відтік метаболітів, що, у свою чергу, розвантажує та підтримує кровоносні судини (рис. 2)

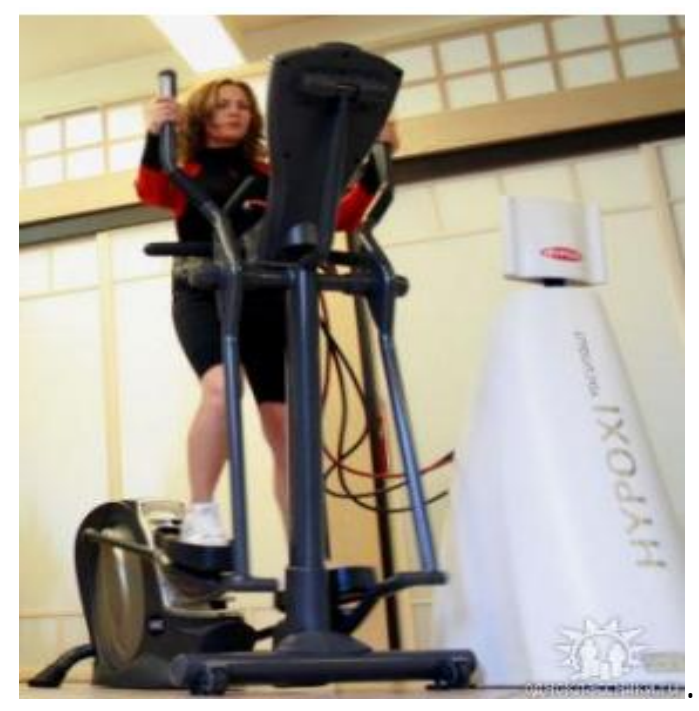

Рис. 2. Тренажери HYPOXI у вигляді капсул із велотренажером

Таким чином, для більш раціонального розвитку фізичних якостей людини варто використовувати сучасні цифрові технології, які ми вважаємо обов'язковою складовою інноваційної рухової активності. 
Висновки та перспективи подальших наукових розвідок. Спорт і фізична культура, поза всяким сумнівом, один із головних засобів виховання рухів, удосконалення їх тонкої та точної координації, розвитку необхідних людині рухових фізичних якостей. Однак, функціональність спорту набагато більш багатогранна, ніж може здатися під час поверхневого вивчення даної сфери людської активності. Поширена думка, що спорт допомагає розвиватися виключно у фізичному плані. Насправді, спорт сприяє становленню гармонійно та всебічно розвиненої особистості, яка легко адаптується в мінливих умовах життєдіяльності, що особливо актуально для сучасного світу. У процесі занять фізичною культурою та спортом загартовується воля, характер, удосконалюється вміння керувати собою, швидко та правильно орієнтуватися в різноманітних складних ситуаціях, своєчасно ухвалювати рішення, розумно ризикувати або утримуватися від ризику. Фізична культура та спорт відіграє важливу соціальну, моральноетичну, ціннісно-орієнтаційну функцію.

Інновації та інноваційна діяльність традиційно представляються як напрям науково-технічного прогресу i як процес, пов'язаний 3 упровадженням результатів наукових досліджень і розробок у практику. Однак, сенс і зміст поняття «інновація» щодо фізичної культури та спорту більш широкий. Сфера інновацій всеосяжна, вона не тільки охоплює практичне використання науково-технічних розробок і винаходів, але й включає зміни в продукті, процесах, маркетингу, організації. Інновація виступає в якості явного фактора зміни, як результат діяльності, втілений у новий або вдосконалений продукт, технологічні процеси, нові послуги й нові підходи до задоволення соціальних потреб. Упровадження інновацій у професійній діяльності фахівців ФКіС передбачає підвищення ефективності рухової активності різних категорій населення через використання інноваційних технологій здоров'я та фітнесу та цифрових технологій спорту та здоров'я.

\section{ЛІТЕРАТУРА}

Allen, L., Nicklesen, L., \& Zgonc, Y. (2008). Prepping the brain: Easy and effective ways to get students ready for learning. Peterborough, New Hampshire: Crystal Springs Books.

Chesbrough, H. (2003). Open innovation: The new imperative for creating and profiting from technology. Boston: Harvard Business School Press.

Comlek, O., Kitapcl, H., Celik, V., \& Ozsahin, M. (2012). The effects of organizational learning capacity on firm innovative performance. Procedia-Social and Behavioral Sciences, 41, 367-374.

Eitzen, D. S., \& Sage, G. H. (2003). Sociology of North American sport. Boston, M A: M cGraw-Hill. Hana, U. (2013). Competitive advantage achievement through innovation and knowledge. Journal of Competitiveness, 5 (1), 82-96. 
Heath, G. W., Parra-Perez, D. C., Sarmiento, O. L., Andersen, L. B., Owen, N., \& Goenka, S. et al. (2012). Evidence-based intervention in physical activity: Lessons from around the world. Lancet, 380 (9838), 272-281.

Hilland, T., Ridgers, N., Stratton, G., Knowles, Z, \& Fairclough, S. (2016). Origins of perceived physical education ability and worth among English adolescents. European Physical Education Review, 1, 16.

Kilborn, M., Lorusso, J., \& Francis, N. (2016). An analysis of Canadian physical education curricula. European Physical Education Review, 22 (1), 23-46.

Kokoulina, O., Simina, T., \& Tatarova S. (2019). Problem and challenges of modern sports. Journal of Physical Education and Sport, 19, 1, 208-213.

Majumder, B., North, J., Mavroudis, C., Rakhit, R., \& Lowdell, M.W. (2012). Improved accuracy and reproducibility of enumeration of platelet-M onocyte complexes through use of doublet-discriminator strategy. Cytometry Part B Clinical Cytometry, 82, 353-359.

Pawłowska, J., Lejzerowicz, F., Esling, P., Szczuciński, W., \& Zajączkowski, M. (2014). Ancient DNA sheds new light on the Svalbard foraminiferal fossil record of the last millennium. Geobiology, 12, 277-288.

Stodolska, M., \& Alexandris, K. (2004). The role of recreational sport in the adaptation of first generation immigrants in the United States. Journal of Leisure Research, 36, 379-413.

Weiss, M., Kimmel, L., \& Smith, A. (2001). Determinants of sport commitment among junior tennis players: Enjoyment as a mediating variable. Pediatric Exercise Science, 13, 131 144.

West, J., \& Gallagher, S. (2006). Challenges of open innovation: The paradox of firm investment in open source software. R\&D M anagement, 36 (3), 319-331.

Wicker, P., Hallmann, K., \& Breuer, C. (2013). Analyzing the impact of sport infrastructure on sport participation using geo-coded data: Evidence from multi-level models. Sport Management Review, 16 (1), 54-67.

\section{PEЗЮME}

Атаманюк Светлана. Использование инновационных видов двигательной активности в профессиональной деятельности специалистов физической культуры и спорта.

Инновационные программы физической культуры и спорта предназначены для

того, чтобы быть более всеобъемлющими, динамичными, подвижными, открытыми, чем традиционные занятия физической культурой и спортом. Это помогает выполнять физические нагрузки и производить приверженность здоровому образу жизни, осуществлять занятия физической культурой и спортом самостоятельно, научить различные слои населения двигательной деятельности, подчеркивая психологическое воздействие физических упражнений на состояние здоровья. Инновационные виды двигательной активности, воплощенные в новых программах, позволяют специалистам физической культуры и спорта развивать у подопечных различные двигательные навыки и способности работать в команде, при этом воспитанники чувствуют себя более комфортно в двигательной среде.

Ключевые слова: специалисты физической культуры и спорта, инновационные спортивные технологии, двигательная активность, технологии здоровья и фитнеса, цифровые технологии спорта и здоровья.

\section{SUM MARY}

Atamanyuk Svitlana. Use of innovative types of motor activity in professional activity of specialists of physical culture and sports.

Innovative programs of physical culture and sports are designed to be more comprehensive, dynamic, mobile, open than traditional physical culture and sports. This helps 
to perform physical exercise and produce a commitment to a healthy lifestyle, exercise physical culture and sports independently, to teach different layers of the population of motor activity, emphasizing the psychological impact of physical exercises on health. Innovative types of motor activity embodied in new programs allow specialists in physical culture and sports to develop various motor skills and ability to work in a team, while pupils feel more comfortable in the motor environment.

Detecting the role of leading elements of movements allows coaches and their ward to focus on decisive movement links and on this basis to achieve an increase in the effectiveness of sports exercises. It is on this basis that the latest innovative types of motor activity are created. Thus, for a more rational development of human physical qualities, it is worth using modern digital technologies that we consider the comprehensive component of innovative motor activity.

Sports and physical culture, beyond doubt, are one of the main means of teaching movements, improving their fine and accurate coordination, developing of the necessary motor physical qualities. However, the functionality of sports is much more multifaceted than it may seem in the brief study of this sphere of human activity. It is a common view that sports help develop exclusively in physical plan. In fact, sports contribute to the formation of a harmonious and comprehensively developed personality, which is easily adapted in changing conditions of life, that is especially relevant for the modern world. In the process of physical culture and sports, the person hardens his will, character, improves the ability to manage himself, quickly and properly navigate in various complex situations, to make decisions, take risks reasonably or refrain from risks. Physical culture and sports play an important social, moral and ethical, valuable orientation function. Innovations and innovative activities are traditionally presented as a direction of scientific and technological progress and as a process are associated with introduction of results of scientific research and development in practice. However, the meaning and content of the concept of "innovation" on physical culture and sports are wider. The scope of innovation is comprehensive, it does not only cover the practical use of scientific and technical developments and inventions, but also includes changes in the product, processes, marketing, organization. Innovation acts as an explicit factor of change as a result of activity embodied in a new or advanced product, technological processes, new services and new approaches to meet social needs. Implementation of innovations in professional activities of FC\&S specialists involves increasing the efficiency of motor activity of various categories of population due to the use of innovative health and fitness technology and digital sports and health technologies.

Key words: specialists of physical culture and sports, innovative sports technologies, motor activity, health and fitness technology, digital sports and health technologies. 